\title{
Perceptions of Foundation Phase Teachers on Principals as Literacy Leaders in Selected Primary Schools
}

\author{
Bernadictus Plaatjies* \\ Department of Education Management and Leadership \\ University of the Free State, South Africa \\ https://orcid.org/0000-0001-7900-7843
}

\begin{abstract}
The bleak picture of South Africa's poor learner performance in international tests is perceived to be linked to ineffective literacy leadership in primary schools. This paper therefore explores the perceptions of foundation phase teachers on principals' capacities as literacy leaders. For this paper, literacy leadership is limited to two facets: instruction and assessment. As such, the study explored teachers' perceptions on principals as leaders in these two aspects. As custodians of the literacy curriculum, teachers possess a wealth of knowledge on instruction and assessment practices. It seems that this rich knowledge and classroom experiences are sometimes untapped into or ignored, which would seem strange and unfortunate. If utilised to the maximum, teachers' knowledge and expertise could contribute immensely to improve literacy practices. This exploratory qualitative study employed a multiple-case study design and was conducted with 35 teachers from four schools in the Mangaung district of Bloemfontein's Free State Department of Education (FSDOE). The study sample was purposefully selected and data were collected through open-ended questionnaires. Thematic analysis was employed to make sense of the data, and the findings disclose that teachers hold conflicting views regarding their principals as literacy leaders. Although some noble leadership practices were underscored, especially regarding internal moderation processes, the general impression was that principals' literacy leadership skills are lacking. This study has highlighted the need for a greater focus on subject-specific leadership in general, but more so for literacy specifically.
\end{abstract}

Keywords: instructional leadership; leadership; literacy; reading; writing

\section{Introduction}

Studies report that the significance of literacy skills (reading and writing) is undisputed. Robust evidence demonstrates that rigorous literacy skills are

*Corresponding author: Bernadictus Plaatjies, Email: plaatjiesbo@ufs.ac.za 
required right from the beginning of school education, through to employment and citizenship (Howie et al., 2017; Spaul, 2012; Gunning, 2014). Bryant and Bradley (1985, cited in Pretorius, 2001) summarised the importance of reading and writing abilities for learners. The authors opined that reading and writing are crucial communicative competencies in the early years of learners. Therefore, paying close attention to learners who experience literacy difficulties is thus vital, as consequences appear to be dreadful. According to Gunning (2014, p. 9), "[r]eading and writing problems, especially when they are severe, affect all aspects of a student's life." To this end, the Department of Education and Training (2018, p. 6) in Australia pointed out in a report that "todays' students need a strong foundation in literacy to be innovative, adaptable and responsive".

Numerous definitions exist for literacy. For De Lange, Dippenaar and Anker (2018), literacy includes the components of reading and viewing, thinking, reasoning and writing. The focus in this paper will only be on reading and writing as literacy components. According to the National Assessment of Educational Progress (NAEP, 2019, p. 3), "reading is a dynamic, active and complex process that involves the understanding of written text, developing and interpreting meaning and using meaning as appropriate to the type of text, purpose and situation." Writing, on the other hand, is regarded by Durga and Rao $(2018$, p. 1) as "an extremely complex cognitive activity in which the writer is required to demonstrate control of variables simultaneously". At the sentence level, these include control of contents, format, sentence structure, vocabulary, spelling and letter formation. Beyond the sentence, the writer must be able to structure and integrate information into cohesive and coherent paragraph and text. The problem in South Africa, though, is that learner performance in literacy is substandard, as confirmed by assessment data from local tests over the last decade. For example, results of the Annual National Assessments in literacy, which are administrated by the country's Department of Basic Education (DBE), concretely demonstrate this poor performance (Spaul, 2012).

South African learners' performance in international tests paints an equally bleak picture. In fact, data from the Progress in International Reading Literacy Study [PIRLS] of 2016 show that South African learners were placed last out of all 50 countries who participated in the PIRLS assessment (Howie et al., 2017). "Even more alarming is the fact that South Africa may be six years behind the top performing countries, and that around $78 \%$ of learners do not reach the international benchmarks and therefore do not have basic reading skills by the end of the gr. 4 school year, in contrast to only $4 \%$ of learners internationally," as Howie et al. (2017, p. 11) explained. Besides, the country's scores in both reading and mathematics are lower than many much poorer countries in sub-Saharan Africa (Spaul \& Taylor, 2015, cited in Taylor \& Hoadley, 2018). South African Minister of Education, Ms. Angie Motshekga, confirmed the challenges associated with literacy by stating that: "Our greatest challenge in this administration has been to tackle the literacy outcomes highlighted in all international, regional and national assessments" (Republic of South Africa [RSA]. DBE, 2013, p. 2).

It appears that school principals have limited capacity to provide direction with teaching and learning. To this end, Hoadley (cited in Bush \& Glover, 2009) and 
Mestry (2017) claimed that many principals lack an extensive understanding of their instructional leadership roles. Although considerable research has been done to address the problems with literacy - especially with regard to classroom practices - less is known on how to approach the challenges from a leadership perspective. It appears that research is particularly scanty regarding principals' knowledge of the literacy curriculum, instruction and assessment and how they should provide support through instructional leadership to teachers.

This is particularly evident in the South African context, characterised as it is by the stark realities of poverty and inequalities. Houck and Novak $(2017$, p. 30) stated that "[v]ery little has been done to examine the specific knowledge that principals require in terms of literacy leadership". Plaatjies (2019, p. 137) contended that "very little is known about how principals should influence literacy instruction through Instructional leadership". Similarly, Hoadley (2018) concurred that the South African research base in this area is very small. These gaps in research are considered against the appeal from scholars in the field of literacy leadership, such as Townsend, Bayetto, Dempster, Johnson and Stevens (2018), who pointed out that principals should play a far more prominent role as literacy instructional leaders. Hence, an in-depth understanding of this role seems to be vital for improved literacy leadership practices. This study aims to close this gap in research by obtaining teacher perceptions on their observations of principals' leadership practices considering literacy instruction and assessment.

Being at the forefront as drivers and custodians of the literacy curriculum, teachers possess a comprehensive understanding of related challenges. For this reason, tapping into this knowledge can provide rich notions on what leaders can do to strengthen instructional practices.

\section{Research Questions}

The following research questions frame this paper: (1) What are foundation phase teachers' perceptions on principals' knowledge of the skills to be taught in the literacy curriculum? (2) What are the perceptions on principals' understanding of literacy assessment requirements? and (3) What are the perceptions on how principals provide support to teachers in literacy instruction and assessment?

\section{Conceptual Framework and Literature Review}

This paper is guided by the guidelines provided by Ravitch and Riggan (2017). They proposed in the guidelines that a conceptual framework "should not only include the relevant theoretical literature, but also the empirical findings of prior research and the researcher's own experiential knowledge, beliefs, commitments and values" (Ravitch \& Riggan, 2017, p. 12). As a starting point, my conceptual framework was informed by relevant and legally binding educational policy documents like the Personnel Administrative Measures (PAM) (DBE, 2015) and the Standard for Principal-ship (DBE, 2016) that outline the leadership roles of South African school principals. These documents are in no way specific as to what principals' leadership roles regarding literacy are. As my study focuses predominantly on the instruction and assessment components of literacy leadership, my conceptual framework was informed by the work of instructional 
leadership expert Phillip Hallinger (2005). The main domains of instructional leadership are quite extensive in scope, and overlapping, in most cases. I therefore demarcated this paper to one aspect of Hallinger's Instructional Leadership Model: the leadership of the (literacy) instructional programme. Focusing on literacy as such, the study is also informed by the Literacy Leadership Model of Taylor and Collins (2003), though focusing only on diligence, instruction and assessment.

\section{The School Principal as Leader of Instruction}

Leadership is next only to instruction amongst school-related impacts on pupil attainment (Manna, 2015). Substantive evidence confirms that instructional leadership in particular is associated with positive student outcomes. Vogel (2018, p. 1) described instructional leadership as "a critical, if not primary task of school leaders", whilst a meta-analysis conducted by Marzano, Walters and McNulty (cited in Vogel, 2018, p. 1) revealed that "principals who were instructional leaders were also found to have a stronger positive impact on student achievement". Regarding the value of subject-specific instructional leadership, Anderson (cited in Bouchamma, 2012, p. 2) declared that "the best outcomes in mathematics and language were linked to instructional leadership". It is not, however, easy to fulfil this role. As recent research from a study on time allocation to instructional leadership indicates: "Principals spent considerable time on running the building and considerably less time on instruction related activities" (Sebastian, Camburn \& Spillane, 2018, p. 90).

Before locating the study in the broader scholarship that exists in literacy leadership, a brief overview of literacy skills, according to the South African Curriculum and Assessment Policy Statement (CAPS) or CAPS curriculum, is presented below. To perform their roles as respected instructional leaders in literacy instruction and assessment, principals should have a sound understanding of the literacy skills to be taught, as stipulated in this curriculum.

\subsection{Overview of literacy skills to be taught in the CAPS curriculum}

The main requirements in the curriculum for the reading component are as follows: Joint reading and writing, group/guided reading, paired/independent reading, and phonics awareness. Emphasis is also placed on the five components of reading instruction, which, according to most reading experts, include: "Phonemic awareness, word recognition (sight words and phonics), comprehension, vocabulary and fluency" (DBE, 2011, pp. 11-13). This list is merely a summary; the policy document contains an exhaustive outline of many other related content and skills. Dole and Nelson (cited in Bean \& Dagen, 2012) declared that knowledgeable literacy leaders know that literacy does not involve only these five parts, and that a firm literacy curriculum needs to be broad. Phonological awareness, letter-sound knowledge, vocabulary, comprehension, fluency and oral composition are referred to as the Big 6 by Townsend et al. (2018), and these are seen as pivotal for reading acquisition. Principals need to safeguard that each element is given satisfactory time, care, and means to allow pupils to study well. In addition, both time and emphasis should be delivered for teachers to permit each element to be debated, advanced, employed, and evaluated in means that 
support educators to see just how fine their learners are succeeding (Townsend et al., 2018). Assessment activities for reading are, in most cases, preceded by informal assessment activities related to phonics (spoken and/or applied/written activities). Other reading skills that require formal assessment activities are developing reading skills, shared reading and group and directed reading (DBE, 2011).

Requirements related to writing for Grade 1 learners include handwriting (including pre-writing programme), shift to a joint script or cursive writing, and materials for scripts. For Grades 2 and 3, the curriculum includes shared writing, writing messages and sentences, writing in present and past tenses, spelling, paragraphs, diaries, punctuation and writing about personal experiences (DBE, 2011). As is the case with reading, CAPS demands that formal writing tasks should be preceded by informal assessments. This also includes a wide array of competencies related to assessing handwriting skills, the development of letter formation, and shared, group and independent writing (DBE, 2011).

\subsection{Principals' commitment to literacy instruction and understanding of the literacy curriculum}

Taylor and Collins (2003, p. 2) argued that "current literacy leadership commences with a commitment from the school leader". He/she should take leadership, otherwise learners will not become skilled readers and writers. Another prerequisite for understanding effective literacy instruction and assessment requires a solid understanding of the tenets of the literacy curriculum. Without an understanding of the literacy content, skills and knowledge, principals will struggle to provide sufficient instructional support to teachers (Alig-Mielcarek, 2003; Taylor \& Collins, 2003). Louis, Leithwood, Anderson and Wahlstroom (2010) warned that lack of familiarity of the curriculum will hamper sound monitoring and support for teacher growth. It is, after all, the principal as the instructional front-runner's responsibility to ensure the application of the core syllabus in the school (Botha, 2013, p. 200). Furthermore, Bouchama (2012, p. 3) stated "that leaders in effective schools distinguish their commitment and expertise by their personal involvement in planning, coordinating and evaluation of the curriculum". In line with this argument, Zimmerman (2017, p. 47) claimed that "[f]or effective school-wide literacy development, school management teams, including principals, heads of department, subject area leaders and all teachers in every subject, need to be actively involved in goal setting, monitoring and implementation".

Scholars agree on the importance and value of sound curriculum knowledge by principals. Plaatjies (2019), for example, linked curriculum knowledge to improvement in instruction, with Munroe (2011, p. 9) positing that "an understanding of each aspect of literacy will enable leadership on where and how to target problem areas". At the same time, Botha (2013, p. 199) opined that "principals need to know about the changing conceptions of the curriculum, educational philosophies and beliefs, knowledge specialisation and fragmentation, curricular sources and conflict, and curriculum evaluation and improvement". 


\subsection{Knowledge and understanding of subject content, instruction and assessment}

One standpoint of instructional leadership proposes that leaders must understand the content of subjects (Stein \& D'Amico, 2000, and Stein \& Nelson, 2003, cited in Sebastian \& Allensworth, 2012). A basic understanding of subject content appears to be necessary to provide well-grounded support in literacy instruction. Pinello (2015) averred that literacy leaders should possess knowledge of literacy instruction, and be able to align curriculum, instruction and assessment (Taylor \& Collins, 2003). Principals in particular should possess a pure and profound understanding of teaching, learning and assessment (Mestry, 2017). A basic understanding of subject knowledge, instruction and assessment and the curriculum will, in turn, empower principals to provide attentive backing connected to lesson planning, structure and content regarding reading and writing, and monitoring and moderation processes. Emanating from the thorough scrutiny of literacy instruction, principals will gain a solid understanding of teachers' expertise. This will, in turn, help principals to provide support in targeted areas where teachers are lacking. This means, in other words, that "the instructional leader needs to have up-to-date knowledge on three areas of (literacy) education namely; curriculum, instruction and assessment" (Du Four, 2002, cited in Kubicek, 2015, p. 704).

\subsection{Assisting teachers through classroom supervision of instruction}

According to Dole and Nelson (cited in Bean \& Dagen, 2012, p. 152), "[1]iteracy leaders know that the instructional delivery of the curriculum is one of the most critically important elements of teaching." Assistance to teachers is therefore vital, and principals may enhance teaching through collaboration in classrooms with teachers or by improving teacher capabilities (Sebastian \& Allensworth, 2012). Many studies provide direction on how principals may provide assistance, overseeing the curriculum across the school. Clear expectations to staff and setting a firm literacy basis for each schoolroom are important (Taylor \& Collins, 2003). Supervision of instruction as instructional leadership duty, for example, may include evaluating the teaching and learning process, teachers' subject knowledge and their lesson planning. Principals should make sure that teachers plan sufficiently by checking their lesson plans (International Literacy Association [ILA], 2019; Klar \& Brewer, 2013). Obliged by the PAM and Standard for Principal-ship policies (DBE, 2015, 2016), principals should ensure that heads of department (HODs) monitor the work of teachers in their subjects (Mestry, 2017).

Herrera (2010, p. 32) claimed that principals should "know what is taking place in the classrooms ... through frequent visits and making suggestions and meaningful feedback on the improvement of quality teaching and learning" (see also AligMielcarek, 2003; Mestry 2017). Classroom observations should be purposefully conducted, focusing on a set of pre-identified and negotiated criteria. The ILA (2019, p. 5), for example, stated that "when principals enter classrooms, they should see and hear students in small groups, working purposefully and collaboratively to solve problems or negotiating the meaning of a text". As part of this purposeful engagement and close monitoring of the instructional programme, 
the process should be accompanied by asking questions about how and why, and supporting innovative attempts to support student learning (Klar \& Brewer, 2013). This process should be accomplished through a persistent emphasis through official and casual consultations with instructors, mentorship, and expert education. Principals should claim the confidence and necessary skills to conduct respectful and productive professional conversations. These should rotate around the improvement of instructional quality (Hoy \& Hoy, 2009, cited in Mestry, 2017). Apart from conducting class visits, principals need to be accessible and visible and provide instructional support by conducting informal walk-throughs (Klar \& Brewer, 2013).

\subsection{Professional development to improve literacy instruction}

Quint, Akey, Rappaport and Willner (2007) (cited in Matsumara, Satoris, Di Prima \& Garnier, 2009) found that enhanced participation of principals in developmental sessions for teachers, with an emphasis on focusing directly on teaching practices, is connected with better execution in the classroom. This leads to improved performance in reading. Sheppard (1996) and Blasé and Blasé (1998) (cited in Kgatle, 2013) likewise opined that instructional leaders must inspire presence at work-related meetings, assemblies and seminars, building a culture of cooperation, knowledge and individual growth. Improved levels of teacher teamwork is related to better learner performance in reading (Spillane \& Hopkins, 2013), whilst in-service training has been meaningfully associated with productive changes in approaches to subjects (Parise \& Spillane, cited in Spillane \& Hopkins, 2013). Pinello (2015, p. 49) asserted that "literacy leaders should establish a team with a coach, build capacity for literacy and provide time for professional development and establish accountability standards". Within these forums, principals should direct the attention to definite tasks of instruction rather than nonconcrete deliberations, exact instructional methods and how to teach specific kinds of content to teachers (Townsend et al., 2018).

\section{Methodology}

An interpretivist paradigm was adopted for this study, which constructs meaning through the participants' own understanding and reflections on their experiences (Adom, Ankrah \& Yeboah, 2018). This qualitative multiple-case study was conducted in four large primary schools (1000+ learners each), involving 35 foundation phase (Grades 1-3) teachers. At School 1, eight teachers completed the questionnaire, at School 2 six, at School 3 eleven and at School 4 ten.

The qualitative approach was deemed appropriate, as I wanted to make sense of participants' perceptions regarding literacy leadership (Marshall \& Rossman, 2011) the researcher opted for the multiple-case-study design, which, according to Creswell and Poth (2018), aims to examine numerous cases to gain insight into an essential phenomenon - in this study, literacy leadership.

To manage the complex process of analysing and interpreting the qualitative data, the researcher used several activities. These included "immersion in the data, organizing these data into chunks (analysis), and bringing meaning to these chunks (interpretation)" (Rossman \& Rallis, 2017, pp. 227-228). McMillan and 
Schumacher (2006) stated that to ensure reliability and honesty, the data should relate with participant responses. The first step during the breakdown of the information was to analyse the unique context of the school, since taking context into consideration is important in multiple-case studies (Creswell \& Poth, 2018). "Contextual features and their influences on the participants' experiences are important for qualitative researchers" (see Maxwell, 2013, p. 30). Data were first presented thematically case by case, followed by cross-case analysis within themes.

As the aim was to offer details as to "how" and "why" heads exhibit leadership in literacy, this researcher also utilised the exploratory and descriptive case study design, as proposed by Yin (2011). The data collection process was supported with the observational method (Appendix 1). Information was collected, described and analysed within the context of each school. This included information about:

- the socio-economic position of the neighbourhood in which the school is located;

- the quality of the school buildings and classes;

- the management of the school with regard to good order; and

- a brief observation about the classroom environment.

Information about the quintile status of the school and years of experience of each principal was obtained from the principals of each school.

The study sample - foundation phase teachers - was selected purposefully as they were, as Creswell (2009, p. 178) concluded, "best suited to address the research problem." Data were collected during the third school quarter of 2019 by means of open-ended questionnaires, a method which, according to Cohen, Manion and Morrison (2018), hooks the truthfulness, fullness, profundity and honesty of responses, trademarks of the qualitative approach. Prior to the distribution phase of the questionnaires, participants were sensitised around the purposes of the research. The questionnaire (Appendix 2) consisted of three broad questions only, and aimed to elicit participants' broad perceptions on principals' knowledge on literacy instruction and assessment:

1. Describe your principal's knowledge of the skills to be taught in the literacy curriculum (reading, writing and assessment).

2. Describe your principal's knowledge of literacy assessment requirements.

3. How does your principal provide support to teachers in literacy instruction and assessment?

\section{Ethical Considerations}

The trustworthiness of the paper was ensured by considering issues of credibility, dependability, conformability and transferability. Credibility was ensured through the process of member-checking and prolonged engagement with the participants. To further guarantee that the responses remained a correct reflection of the data provided in the questionnaires, participants had to be given the opportunity to read the interpreted data. Findings were verified with the help of a colleague to ensure that they are consistent with the data collected. This ensured the dependability of the research. Conformability of the research was ensured by 
adhering to what Gasson (2004, p. 93) proposed: “... findings should represent, as far as is (humanly) possible, the situation being researched rather than the beliefs, pet theories, or biases of the researcher." Transferability was safeguarded through providing sufficient information about the researcher, the research context and processes to allow the reader to select in what way the outcomes can be transferred (Morrow, 2005).

Ethical clearance was granted by the University of the Free State (ethics approval number UFS-HSD 2019/0087/1808), whilst authorization to conduct the study was gained from the Free State Department of Education (FSDOE). Informed approval was attained from all the participants of the four participating schools prior to the start of the study. Ethical issues considered were drawn from the advice of Cohen et al. (2018). These included participants' rights to pull out at any phase or not to complete specific items in the questionnaire; an agreement that the research will not harm them (the principle of non-maleficence); and the guarantees of confidentiality, anonymity and non-traceability in the research. To ensure namelessness, acronyms were used to classify the partakers. Under the discussion of each respective school, $\mathrm{T}$ is used for teacher, with the number of the relevant participant for that school (e.g. T1-T8 for School 1, T1-T6 for School 2; etc.).

\section{The Role of the Researcher}

This researcher, see himself as a social constructivist in the research environment. He seek what Creswell (2013, p. 24) described as an approach of individuals (researchers) who seek "an understanding of the world in which they live and work" and to "develop subjective meanings of their experiences". His research focus centres on the core business of the schooling enterprise, teaching and learning in the classroom, but mainly from a leadership approach regarding instruction. Classrooms are dynamic and complex spaces. Harvard professor Richard Elmore (cited in Schmoker, 2006, p. 14) described classrooms as an area protected by a buffer, "... a protective barrier that discourages and even punishes close, constructive scrutiny of instruction ... the buffer ensures that we know very little about what teachers teach, or how well they teach." Principals, as instructional leaders, may thus sometimes find it difficult to gain deep knowledge and experiences of instructional practices in the classroom. With the approach of providing open-ended questionnaires, the aim was to not pressurise participants by intruding on their buffers. Through the use of open-ended questionnaires, "the researcher can listen carefully to what people say and do in the life setting" (Creswell, 2013, p. 25).

\section{Presentation of the Findings}

With referral to the contextual aspect, South African government schools are subjected to a quintile system, where all schools are allocated into one of five categories. This categorisation is due to the country's wide economic disparity, the issue of socio-economic status and the disparity between rich and poor schools. The schools in the most economically deprived (poorest) geographic parts are categorised as quintile 1, 2 and 3 schools, and those in the greatest economically privileged (wealthiest) environmental areas as quintile 4 and 5 schools. Schools in quintiles 1 to 3 are non-fee-paying schools and receive more funding per learner 
from the government than schools in quintiles 4 and 5 (Ogbonnaya \& Awuah, 2019). Below follows a discussion on each participating school, it's context and the related findings.

\subsection{School 1}

\section{Contextual description}

This quintile 3 school is located in a neighbourhood characterised by mixed-income housing. Although the reality of poverty and low economic status is evident in the neighbourhood, the infrastructure of the school is sound, and classes are neat with colourful decorations. The dedicated principal has more than 20 years' experience in this position. The school appeared to be well managed. Eight literacy teachers completed the questionnaire.

Theme 1: Perceptions on the principal's knowledge of the skills to be taught in the literacy curriculum

The findings on this theme indicate that the participants of this orderly school perceived their principal to have a good understanding of the CAPS literacy curriculum. According to them, this dedicated principal is well informed about the subject content to be taught in literacy. Furthermore, she is well aware of the skills to be taught related to reading and writing. This understanding of the literacy curriculum is interestingly enough contributed to her experience as a language teacher:

"Fortunately my principal was a language teacher, she therefore understand the curriculum." (T1)

Theme 2: Perceptions on the principal's knowledge of literacy assessment requirements On the question of how the participants would describe their principal's understanding of literacy assessment requirements, the feedback demonstrates that the principal possesses a good understanding of the requirements. She knows the prescribed amount of assessment tasks to be conducted and ensures their completion according to the CAPS guidelines. According to one of the participants, her knowledge of assessment can also be attributed to her being a language teacher:

"She understand the assessments because she was a teacher herself." (T3)

Theme 3: Perceptions on how the principal provides support in literacy instruction and assessment

Good support is provided to teachers in the form of professional learning communities and development, workshops and subject meetings. The following excerpts are evidence of the types of support that the principal provides:

T1 and T3: "We participate in professional learning committees (PLC)."

"She also makes educators aware of opportunities of professional development." (T4)

"She encourages us to have subject meetings regularly, and attend workshops." (T3)

Participants also revealed that internal moderation processes and supervision form part of the support strategy to improve literacy instruction and assessment. T4 proclaimed that these processes are performed mainly by the HODs and grade 
heads. This is confirmed by T5, who explained that the HOD conducts pre- and post-moderation of all the work done, including assessment activities. The literacy instructional programme is further monitored by HODs via the Integrated Quality Management System (IQMS), class visits and the inspection of learners' workbooks. According to one of the participants (T6), the principal follows up with HODs and intervenes where needed.

\subsection{School 2}

\section{Contextual description}

This school is located in a low-income area with visible signs of severe poverty. Because of this factor, the school has a quintile 2 status. The school building is brand new, and classes are spacious and well furnished. The learning environment in classes is bare, though, with very few classes that have evidence of print-rich literacy environments. The principal has five years' leadership experience. Six questionnaires were completed at this school.

Theme 1: Perceptions on the principal's knowledge of the skills to be taught in the literacy curriculum

The data on this question show that participants viewed their principal's knowledge of the literacy curriculum as unsatisfactory. Participants who held this opinion criticised him because of un-involvement and lack of commitment in the foundation phase. They regarded the attention to literacy instruction as insufficient. Others opined that the principal is a former mathematics teacher, which they regard as the main reason for his lack of knowledge and commitment to provide leadership in literacy. The issue of an inadequate understanding of the literacy curriculum because of subject experience and involvement as a teacher is evident in this case. One of the participants (T2) asserted:

"The principal is not much involved with language as a whole, since he was mathematics educator for 27 years, he normally says that his understanding about language is little."

Theme 2: Perceptions on the principal's knowledge of literacy assessment requirements In response to the question on the principal's knowledge of literacy assessment requirements, the findings display that this principal lacks a respectable understanding. The principal's insufficient understanding of literacy assessment is revealed by comments such as: "he need guidelines regarding assessments related to literacy curriculum" (T1) and "does not have knowledge of the foundation phase" (T3). These comments by participants refer once again to the issue of how not being a language or literacy teacher impacts principals' knowledge in this regard. Concerning this, T4 openly stated:

"His knowledge regarding the requirements in reading and writing can be limited because he specialise in another subject area."

Theme 3: Perceptions on how the principal provides support in literacy instruction and assessment

This theme elicited very little feedback from the participants. They merely indicated "good" or "not so good" or had poor responses on the question of how they would describe the principal's support to teachers. Participants viewed the 
principal as uninvolved in supporting teachers in the teaching and learning of literacy.

\subsection{School 3}

\section{Contextual description}

This neat and well-organised school is located in the same neighbourhood as School 2 and falls under the same quintile (2). The principal at this school has more than 30 years of experience. Although the school building is old, it is well looked after and the classes appear also to be conducive for literacy learning. Eleven literacy teachers completed the questionnaires at this school.

Theme 1: Perceptions on the principal's knowledge of the skills to be taught in the literacy curriculum

Most of the participants from this school felt that the principal displays adequate knowledge of the literacy curriculum. They ascribed the principal's knowledge to her years of experience. Their responses to this question indicate that the principal places much emphasis on the reading component of the literacy curriculum. T4 mentioned:

"She would come during class visits and motivates learners to engage in reading activities. She asks them to explain with which reading activities they are busy with."

This principal scrutinises relevant literacy policy documents which empower her to have an enhanced understanding of assessment requirements. It is also apparent that the principal and the school management teams (SMTs) have sound planning systems in place. This includes an approach where the assessment programme is provided to learners and parents at the commencement of every school year. The aim is to guarantee awareness of when formal assessment tasks will be conducted. In language departmental meetings, the emphasis is on informal activities. The good practices by the principal regarding the implementation of the literacy assessment policy are supported by the following remark by one of the participants:

"She makes sure activities are well coordinated, and that the school have a Programme of Assessment as well as School assessment Plan. Formal tasks for all grades and subjects which is shared with the parents and guardians." (T8)

Theme 2: Perceptions on the principal's knowledge of literacy assessment requirements The feedback by participants points out that the principal has a solid understanding of the promotional requirements regarding the literacy curriculum. Being a language teacher herself, she is attuned to a good understanding of assessment as well. This point is reflected in the following statement:

"She has taught English, I believe that she has the knowledge regarding everything in English." (T7)

Theme 3: Perceptions on how the principal provides support in literacy instruction and assessment

On the question of how the principal assists teachers in literacy teaching, findings reveal that the principal employs various strategies for additional literacy 
instruction opportunities. For example, T4 alluded to the fact that their principal implements marathon classes, whereas $\mathrm{T} 6$ opined that the principal supports each phase's initiative plans. T8 and T7 said that their principal provides feedback to all phases and offers support wherever she is able, within the IQMS setup. Support to teachers also entails internal moderation processes by the HOD and grade heads, who conduct pre- and post-moderation. These SMT members also conduct moderation of assessment activities and supervise instruction on behalf of the principal, as mentioned by T9.

\subsection{School 4}

\section{Contextual description}

This school also has a quintile 2 status. The principal is newly appointed, with only one month's experience in this role. The school buildings are solid, but very filthy. The school appeared to be noisy and overcrowded. The classes are also not very neat and, in some places, have graffiti on the walls. Ten teachers filled in the questionnaires at this school.

Theme 1: Perceptions on the principal's knowledge of the skills to be taught in the literacy curriculum

The participants from this school also opined that their principal has a solid understanding of the skills within the literacy curriculum. This knowledge is linked to his experience as a language teacher. This argument is reflected by the following two participants' responses:

"The principal is a language teacher and have a broad knowledge of literacy." (T2)

"Our principal was a former language teacher. He is very much aware of the requirements because he is himself a language teacher." (T8)

Theme 2: Perceptions on the principal's knowledge of literacy assessment requirements Participant replies regarding their principal's understanding of literacy assessment reveal that the principal lacks a respectable understanding of this aspect. This led to the "principal provide sometimes [sometimes providing] contradicting commands" (T4). The principal's insufficient understanding of assessment was further revealed by comments such as "he need guidelines regarding assessments related to literacy curriculum" (T6).

Theme 3: Perceptions on how the principal provides support in literacy instruction and assessment

Feedback on this question indicates that the principal, other members of the SMT, and teachers do not attend training opportunities provided by the Department of Education. This lack of dedication and commitment is evident in the following comments:

"We attend training, but not all teachers were involved in the training.

Subject coordinators and HODs does [sic] not always go to trainings."

"Also important is the fact that principals themselves do not attend these workshops and training, and some are not even involved in the foundation phase: He is more involved at gr. 4-7." (T9). 
Quarterly subject meetings appeared to be a popular way to address literacy challenges. "HOD'S and principals keep teachers informed about recent developments in literacy instruction," T8 mentioned. Interestingly enough, though, is that participants pointed out the existence of reading, poetry, speech and spelling competitions at their school.

\section{Discussion and Analysis of the Findings Across Cases}

\section{Context}

The data reveal that all participating schools are located in communities with high poverty rates, with School 1 exposed to a lesser degree to contextual challenges than the other three schools, due to the mixed-income factor. Research demonstrates that providing instructional leadership in such disadvantaged environments can be a daunting exercise. Consequently, it may be difficult to provide rich learning opportunities to vulnerable and at-risk learners (Scott, 2017). Despite the locations of the schools, the infrastructure and general neatness of the schools were sound, except for School 4 . This can probably be attributed to the lack of experience and low commitment levels of the principal. Only School 3 displayed evidence of a print-rich literacy environment, which is a sign of what Manna (2015) regarded as vital for effectiveness for serving children with the fewest advantages in life. Schools appeared to be in good order, except for School 4.

The findings are discussed below based on the research questions, themes presented and in conjunction with the literature review.

\section{Research Question 1:}

\section{Perceptions on principals' knowledge of the skills to be taught in the literacy curriculum}

The views of the participating foundation phase teachers across the participating schools indicate contradicting findings on this theme. Participants at Schools 1 and 3 opined that their principals have a firm grounding of literacy instruction and the literacy curriculum. These excellent principals' sound knowledge is attributed to their subject-teaching experience. Both these leaders also have many years of experience as principals. These factors enable them to provide sound direction with respect to literacy instruction. Manna (2015) declared that excellent principals can have a powerful impact on teachers.

The participants from Schools 2 and 4, though, felt that their principals' knowledge base with respect to literacy is wanting. This finding is in line with previous research, which indicates that curriculum and instructional knowledge is lacking amongst some South African principals (Kgatla, 2013; Taylor \& Hoadley, 2018; Plaatjies, 2019). It is also clear from the data that the principals of School 2 (a former mathematics teacher) and School 4 (a newly appointed principal) lack commitment and experience. It is furthermore possible that work overload, inadequate time, contextual challenges and the new position of principalship might be overwhelming. This finding is in line with what Mestry (2017) determined regarding principals who experience countless problems in matching varied organisational obligations with their curriculum headship tasks. This therefore 
questions whether principals have the capability to take on all the responsibilities by themselves.

The lack of sufficient curriculum and instructional knowledge amongst principals may have enormous repercussions. It can complicate matters to provide strong curriculum coordination and instructional support, and it hampers trust and respect towards principals (Taylor \& Hoadley, 2018). Teachers expect their leaders to possess expertise as instructional and curriculum leaders (see Dempster et al., 2017) and smart principals are aware of this. Leithwood, Louis, Anderson and Wahlstroom (2004, p. 11) even went so far as to argue that "the curricular knowledge of successful elementary principals frequently rivals the curricular knowledge of their teachers".

Not surprising, though, is that where principals display a lack of knowledge of the literacy curriculum, it is ascribed to them not teaching the subject (as is the case with School 2). This finding is consistent with what Key (cited in Pinello, 2015, p. 46) found: “... principals with reading instruction backgrounds were found to be more attentive to literacy instruction and also have a better overall knowledge of literacy". Strangely enough, this finding is partially in contrast to what is expected from principals as instructional leaders. As Townsend et al. (2018, p. 207) put it: "there is a need for principals to have good content knowledge about literacy." According to this viewpoint, it is a prerequisite for principals to have sound knowledge, irrespective of being a subject teacher or not in literacy.

\section{Research Question 2:}

\section{Perceptions on principals' knowledge of literacy assessment requirements}

The data demonstrate that the principals from Schools 1 and 3 are knowledgeable regarding literacy assessment requirements. This is in line with what Lear (2017) proposed, that principals should have a have a deep understanding of the various components of literacy learning, including assessment-based instruction. Their knowledge is ascribed to possessing teaching experience in literacy and languages, whereas the lack of knowledge of the principals of Schools 2 and 4 is once again ascribed to not having this kind of teaching experience. Very little feedback was given on this aspect, especially by the participants of School 2. This gave the impression of a lack of leadership and management attention by principals. Zimmerman (2017) confirmed that many South African primary schools do not have management and planning structures and strategies.

A pleasant finding is the emphasis that the two principals of Schools 1 and 3 put on internal moderation processes to evaluate assessment practices. The question remains unanswered, however, whether these promising efforts are sufficient to meticulously adhere to the monitoring and moderation of assessment requirements. Dole and Nelson (cited in Bean \& Dagen, 2012, p. 149) stated in this regard that "literacy leaders need to be effective leaders in assisting teachers to monitor carefully what is taught in literacy". The data did not conclude, though, whether a well-coordinated internal moderation plan was present to rigorously attend to every aspect of literacy instruction and assessment. Zimmerman (2017) warned that in these non-privileged settings, such managerial ineffectiveness 
could lead to a lack of coordination of teaching practices across grades and phases. Townsend et al. $(2018$, p. 207) were of the view that such an approach should be encouraged by solid evidence of learners' abilities, so that what they need to do subsequent is well aground. This should be supported by subject meetings conducted at least twice per quarter.

\section{Research Question 3:}

\section{Perceptions on how principals provide support in literacy instruction and assessment}

The data reveal that Schools 1 and 3 displayed some noteworthy practices regarding the assistance that principals provide to teachers in literacy instruction and assessment. The orderly environments and many actions in support of teachers are evidence of these principals' commitment. This finding confirms the association between principals' actions and dedication and improvement in instruction and assessment. Manna (2015) raised this issue by claiming that principals can, through their engagements, be influential multipliers of active instruction and guidance practices in schools. Similarly, Zimmerman (2017, p. 39) pointed out that "high performing schools serving low-income learners need a safe, orderly and positive environment, strong leaders, excellent teachers, competent, committed, caring, collaborative teachers with a sense of pride, competence and purpose of the school".

The lack of involvement by the principals of Schools 2 and 4 is also evident under this theme. According to Hoadley (2018), a neglected aspect with respect to literacy leadership is the attention to the management of reading activities. This may be because of principals' lack of subject knowledge and experience. This view is supported by Pinello (2015), who claimed that several managers lack the essential information and abilities to successfully upkeep literacy development. Superville (2019) warned, however, that it might be unrealistic and unfair to expect principals to possess deep content knowledge of all the subjects taught, including subjects that they may not have taken when they were students. Given the lack of attention to the issue, it is quite interesting to note that Schools 1 and 4 hold regular subject meetings as part of a support strategy.

Participants did not elaborate in detail on what the assistance from principals entails, giving the impression that sufficient planning and monitoring are lacking. For Zimmerman (2017), planning and monitoring of literacy teaching and learning are key activities which lead to high levels of accountability in the school management structure. In almost all the responses, participants indicated only one or another form of support, and not varied forms of support. This ranged from the popular subject meeting to professional learning development. For example, participants did not indicate how professional learning groups address improvement in specific components of literacy instruction and assessment. Neither did they provide details on how committees, workshops and training deal with challenging aspects related to literacy instruction. These findings seem to be consistent with Mbhalati (2017) and Bomer and Maloch's (2019) work, in which they claimed that professional development strategies in literacy instruction are lacking. A possible explanation for this might be the difficulties associated to get 
everyone involved in professional development activities, as this can be a tricky exercise (Bomer \& Maloch, 2019).

These forms of teacher supervision are supported by Bouchamma $(2012$, p. 3) "as part of a committed principal's PD [professional development]-strategy" and by Townsend et al. (2018, p. 207), who preferred "a commitment to focused professional conversations, or disciplined dialogue". The participants' vague explanations on what professional development activities entail provide the impression that neither the participants as teachers nor the principals really possess an in-depth understanding of what professional development activities for literacy entail. This finding appears to indicate a possible lack of intellectual engagement on literacy instruction, and is confirmed by Mestry (2017), who claimed that principals hardly offer knowledgeable direction for progress on instructional matters.

It is interesting to note that the role of HODs as instructional leaders were highlighted overwhelmingly, especially in Schools 1, 3 and 4. This in line with the desired approach of shared leadership as by Guth and Pettingull (cited in Pinello, 2015). Principals cannot make the essential inroads alone toward a fruitful literacy programme which includes supporting classroom instruction (Pinello, 2015). HODs' involvement as literacy leaders can be ascribed to principals' heavy workloads, a distributed leadership approach by principals and/or adhering to the related policy requirements, which require involvement of the entire SMT. The Standard for Principal-ship document, for instance, places a responsibility on principals to "empower staff to become instructional leaders who share the responsibility for achieving the mission, vision and goals that have been set" (DBE, 2016, p. 21). The PAM document (DBE, 2016, p. 27), on the other hand, requires that the "Departmental Head should co-ordinate evaluation/assessment, written assignments, etc. of all the subjects in that department". Interestingly enough, only participants from School 4 referred to support including specific content-related strategies.

A rather disappointing finding in the study is that there is little evidence of classroom visits, observation of lessons and visibility of principals. None of the participants alluded to this aspect of instructional leadership. Hallinger (2011) stated that this direct oversight and maintaining of instructional oversight do pay off. Also absent from the participants' feedback is how principals address instructional challenges through formal and informal discussions with teachers, classroom visits and observations, and other forms of targeted professional development activities. Superville (2019) pointed out that a firm grounding by the principal in the classroom environment is necessary to have educated conversations with teachers about strengths and weaknesses. It seems that principals possibly do not have the expertise, motivation or enough time to perform these crucial functions. Mestry (2017) concurred that most principals devote little periods in classrooms and even fewer time analysing syllabus delivery with educators. 


\section{Conclusion}

This paper set out to determine the perceptions of foundation phase teachers on principals as literacy leaders in selected primary schools. Focusing only on the components of instruction and assessment, this study extended knowledge of principals' leadership abilities in this regard.

The findings suggest that some principals have a sound knowledge of the literacy curriculum. Those who lack knowledge will be unable to provide strong instructional leadership, which can hamper teachers in developing deep, engaging literacy lessons for foundation phase learners. On the other hand, sound knowledge of the curriculum and instruction may ground principals to provide educated support to teachers. This is especially vital in the challenging highpoverty contexts. To address the deficiency on literacy curriculum knowledge amongst principals, it is recommended that the four schools engage in a collaborative professional development strategy.

With regard to the second research question, the findings indicate almost similar outcomes on the competency and commitment levels of the respective principals. The implication of this finding is that principals will struggle to provide in-depth support to teachers in assessment practices. They should therefore undergo training to obtain a basic understanding of the literacy assessment framework.

The data suggest that principals utilise a variety of strategies to support teachers with instruction. However, the data also show less support with respect to assessment. Consequently, teachers' understanding regarding assessment may not be up to standard. To this end, continuous professional development and training sessions should be comprehensive in addressing the needs of teachers with regard to support.

Any research project has its limitations and this one is no exception. With regard to the methodology employed, a mixed methods approach may have provided more clarity on principals' knowledge of subject content, assessment and instruction. The quantitative aspect of a mixed methods design might have classified the frequency of principals' engagement in instructional leadership duties such as supervision and classroom observation.

\section{References}

Adom, D., Ankrah, A., \& Yeboah, A. (2018). Constructivism philosophical paradigm: Implication for research, teaching and learning. [online] Eajournals.org. Retrieved from http://www.eajournals.org/ wp-content/uploads/ConstructivismPhilosophical-Paradigm-Implication-for-Research-Teaching-and-Learning.pdf

Alig-Mielcarek, J. M. (2003). A model of school success: Instructional leadership, academic press, and student achievement (Doctoral dissertation). Ohio State University, Columbus, Ohio.

Bean, R. M., \& Dagen, S.W. (2012). Best practices of literacy as leaders. Keys to school improvement. New York, NY: Guilford Press.

Bomer, R., \& Maloch, B. (2019). Lessons for leaders on the preparation of literacy educators. Journal of Literacy Research, 51(2), 259-264. 
Botha, R. J. (2013). The effective management of the school: Towards quality outcomes. Pretoria: Van Schaik.

Bouchamma, Y. (2012). Leadership practices in effective schools in disadvantaged areas of Canada. Educational Research International, 2012(2). doi:101155/2012/712149

Cohen, L., Manion, L., \& Morrison, K. (2018). Research methods in education (8 $8^{\text {th }}$ ed.). New York, NY: Routledge; Oxon.

Creswell, J. W. \& Poth, C. N. (2018). Qualitative inquiry E research design: Choosing among five approaches (4 ${ }^{\text {th }}$ ed.). Los Angeles: Sage.

Creswell, J. W. (2009). Research design: Qualitative, quantitative and mixed methods approaches (3rd ed.). California: Sage.

Creswell, J. W. (2013). Qualitative inquiry E research design: Choosing among five approaches (3rd ed.). Thousand Oaks, CA: Sage.

De Lange, M., Dippenaar, H., \& Anker, J. (2018). Shared writing as first phase in writing instruction of Intermediate Phase Afrikaans Home Language learners. Per Linguam 34(1), 33-46. doi:10.5785/34-1-704

Dempster, N., Townsend, T., Johnson, G., Bayetto, A., Lovett, S., \& Stevens, E. (2017). Leadership and literacy: Principals, partnerships and pathways to improvement (e-book). Cham, Switzerland: Springer. doi:10.10007/978-3-319-54298-0

Department of Basic Education (DBE). (2011). National Curriculum Statement (NCS). Curriculum and Assessment Policy Statement. English Home Language. Foundation Phase Grades R-3. Pretoria: Government Printer.

Department of Basic Education (DBE). (2015). Policy on the South African Standard for Principalship. Enhancing the professional image and competencies of school principals. Retrieved from https://www.sapanational.com/files/POLICY-ON-THE-SASP-2-.pdf

Department of Basic Education (DBE). (2016). Personnel Administrative Measures (PAM). Retrieved from https://www.naptosa.org.za/doc-manager/30-labourmatter/archived/920-pam/file

Department of Education and Training. (2018). Literacy and numeracy strategy phase 2. Achieving excellence and equity in literacy and numeracy. The Education State. Retrieved from: https://www.education.vic.gov.au/Documents/school/teachers/teachingresou rces/literacynumeracy/Literacy_and_Numeracy_Strategy_Phase_2.pdf

Durga, V.S. S., \& Rao, C. S. (2018). Developing students' writing skills in English: A process approach. Journal for Research Scholars and Professional English Language Learning, $6(2), 1-5$.

Gasson, S. (2004). Rigor in Grounded Theory research: An interpretive perspective on generating theory from qualitative field studies. In M.E. Whitman \& A.B. Woszczynski (Eds.), The handbook of information systems research (pp. 79-102). Hershey, PA: Idea Group.

Gunning, T. (2014). Assessing and correcting reading and writing difficulties (5 $5^{\text {th }}$ ed.). Boston: Pearson.

Hallinger, P. (2005). Instructional leadership and the school principal: A passing fancy that refuses to fade away. Leadership and Policy in Schools, 4, 1-20.

Hallinger, P. (2011). Leadership for learning: Lessons from 40 years of empirical research. Journal of Educational Administration, 49(2), 125-142.

Herrera, R. (2010). Principal leadership and school effectiveness: Perspectives from principals and teachers (Doctoral dissertation, Western Michigan University, Kalamazoo, Michigan). Dissertations. $568 . \quad$ Retrieved from http:/ / scholarworks.wmich.edu/dissertations/568 
Hoadley, U. (2018). RESEP working paper. Leading for literacy: A Review of the research. Stellenbosch working paper (No. WP 19/2018). Stellenbosch: University of Stellenbosch.

Houck, B., \& Novak, S. (2017). Leading the way in literacy: Classroom visits offer a comprehensive view of teaching on learning. The Learning Professional, 38(5), 30-34.

Howie, S. J., Combrinck, C., Roux, K., Tshele, M., Mokoena, G. M., \& McLeod Palane, N. (2017). PIRLS Literacy 2016. Progress in International Reading Literacy Study 2016: South African Children's Literacy Achievement. Pretoria: Centre for Evaluation and Assessment. Retrieved from https://www.up.ac.za/media/shared/164/ZP_Files/pirls-literacy-2016_grade4_15-dec-2017_low-quality.zp137684.pdf

International Literacy Association (ILA). (2019). Principals as literacy leaders [Literacy leadership brief]. Newark, DE: ILA.

Kgatla, M. E. (2013). Principals' perceptions of their instructional leadership role in the improvement of numeracy and literacy in primary schools (Master's dissertation). University of Pretoria.

Klar, H. W., \& Brewer, C. A. (2013). Successful leadership in high-needs schools: An examination of core leadership practices enacted in challenging contexts. Educational Administration Quarterly, 49(5), 768-808.

Kubicek, M. R., (2015). Principals' use of classroom walkthrough observations to improve instruction: a grounded theory. (Doctoral dissertation, University of Nebraska, Lincoln, Nebraska). Retrieved from Lear, M.L. (2017). Principal perceptions as literacy leaders at high-need elementary schools (Doctoral dissertation, University of Denver, Denver, Colorado). Retrieved from https:/ / digitalcommons.du.edu/cgi/viewcontent.cgi?article=2244\&context=etd

Leithwood, K. A., Louis, K. S., Anderson, S., \& Wahlstroom, K. (2004). Review of research: leadership influences student learning. Retrieved from http:/ / conservancy.umn.edu/bitstream/handle/11299/20135/1/CAREI\%Revie wofResearch \% 2\%20Leadership \%20Influences.pdf

Louis, K. S., Leithwood, K., Anderson, S., \& Wahlstroom, K. (2010). Investigating the links to improved student learning: Final report of research findings. University of Minnesota: Wallace Foundation.

Manna, P. (2015). Developing excellent school principals to advance teaching and learning: Considerations for state policy. The Wallace Foundation. Retrieved from https://www.wallacefoundation.org/knowledgecenter/Documents/Developing-Excellent-School-Principals.pdf

Marshall, C., \& Rossman, G. (2011). Designing qualitative research (5 th $^{\text {th }}$.). California: Sage.

Matsumara, L. C., Satoris, M., Di Prima, B., \& Garnier, H. E. (2009). Leadership for literacy coaching: The principal's role in launching a new coaching program. Educational Administration Quarterly, 45(5), 655-693. doi:10.1177/0013161X09347341

Maxwell, J. A. (2013). Qualitative research design: An interactive approach (3 ${ }^{\text {rd }}$ ed.). Thousand Oaks, CA: Sage.

Mbhalathi, N. B. (2017). Instructional guidance for literacy teaching in Limpopo, South Africa: A case study of the foundation phase policy and practice (PhD thesis). University of the Free State, Bloemfontein.

McMillan, J. H., \& Schumacher, S. (2006). Research in education: Evidence-based inquiry. Boston: Pearson.

Mestry, R. (2017). Empowering principals to lead and manage public schools effectively in the 21st century. South African Journal of Education. 37(1), 1-11. 
Morrow, S. L. (2005). Quality and trustworthiness in qualitative research in counselling psychology. Journal of Counselling Psychology. 52(2), 250-260. doi:10.1037/00220167.52.2.250

Munroe, J. (2011). Principals as leaders in literacy: A strategy for literacy improvement in primary schools. What Works. The Work Program: Core Issues 11. Retrieved from http://www.whatworks.edu.au/upload/1348031338415_file_CoreIssues11.pdf

National Assessment of Educational Progress (NAEP). (2019). Reading framework for the 2019 national assessment of educational progress. Washington, DC: National Assessment Governing Board: US Department of Education.

Ogbonnaya, U. I., \& Awuah, F.K. (2019). Quintile ranking of schools in South Africa and learners' achievement in probability. Statistics Education Research Journal, 18(1), 106-119.

Pinello, G. S. (2015). A regression study: Middle school literacy leadership practices in Virginia. (Doctoral dissertation). George Washington University, Washington D.C.

Plaatjies, B. O. (2019). Investigating principal capacity in literacy instructional leadership at selected primary schools. Journal of Social Studies Education Research, 10(3), 136-160.

Pretorius, U. (2001). 'n Geletterdheidsgereedmakingsprogram en die implikasies daarvan vir skoolgereedheid: 'n Sielkundig-opvoedkundige perspektief [A literacy preparation program and its implications for school readiness: A psychological-educational perspective] (PhD thesis). Unisa, Pretoria.

Rossman, G. B., \& Rallis, S. F. (2017). An introduction to qualitative research: Learning in the field ( $4^{\text {th }}$ ed.). Los Angeles: Sage.

Schmoker, M. (2006). Results now: How we can achieve unprecedented improvements in teaching and learning. Alexandria, VA: Association for Supervision and Curriculum Development.

Scott, M. R. (2017). Challenges of Instructional leadership in Manitoba First Nation Schools: An exploration of what principals have to say (PhD thesis). University of Manitoba, Winnipeg, Canada.

Sebastian, J., \& Allensworth, E. (2012). The influence of principal leadership on classroom instruction and student learning: A study of mediated pathways to learning. Educational Administration Quarterly, 48(4), 626-663. doi:10.1177/0013161X11436273

Sebastian, J., Camburn, E. M., \& Spillane, J.P. (2018). Portraits of principal practice: Time allocation and school principal work. Educational Administration Quarterly, 54(1), 47-84. doi:10.1177/0013161X17720978

Spaul, N. (2012). The inequalities that lead to pupils' poor performance. The University of the Free State, Bloemfontein: SA Media.

Spaul, N. (2014). Education quality in South Africa and Sub-Saharan Africa: An economic approach (PhD thesis). University of Stellenbosch, Stellenbosch.

Spillane, J. P., \& Hopkins, M. (2013). Organizing for instruction in education systems and school organizations: How the subject matters. Journal of Curriculum Studies, 45(6), 721-747. doi:10.1080/00220272.2013.810783

Superville, D. R. (2019). How deeply principals should know content areas and how much it matters for helping teachers in an active debate. Education Week, 39(9), 14-16.

Taylor, N., \& Hoadley, U. (2018). Leadership for literacy: Exploring leadership practices in township and rural primary schools serving poor communities in South Africa. Final report on the case study schools. University of Stellenbosch, Department of Economics: RESEP.

Taylor, R., \& Collins, V.D. (2003). Literacy leadership for Grades 5-12. Alexandria, VA: Association for Supervision and Curriculum Development. 
Townsend, T., Bayetto, A., Dempster, N., Johnson, G., \& Stevens, E. (2018). Leadership with a purpose: Nine case studies of schools in Tasmania and Victoria where the principal had undertaken the Principals as Literacy Leaders (PALL) Program. Leadership and Policy in Schools, 17(2), 204-237. doi:10.1080/15700763.2016.1278245.

Vogel, L. R. (2018). Learning outside the classroom: How principals define and prepare to be instructional leaders. Education Research International, Article ID 8034270, 1-14. doi:10.1155/2018/8034270

Yin, R. K. (2011). Qualitative research from start to finish. New York: Guilford Press.

Zimmerman, L. (2017). Learning from the best: Reading literacy development practices at a high-performing primary school. Per Linguam, 33(2), 36-50. doi:10.5785/33-2-740 